\title{
Terras Indígenas e ICMS Ecológico no Tocantins: os casos Xerente e Apinajé
}

\section{Indigenous Lands and the Ecological ICMS in Tocantins: the Xerente and Apinajé cases}

\section{Las Tierras Indígenas y el ICMS Ecológico en Tocantins: los casos Xerente y Apinajé}

http://dx.doi.org/10.21713/2358-2332.2016.v13.1024

Héber Rogério Grácio, doutor em Antropologia pela Universidade de Brasília (UnB) e professor da Universidade Federal do Tocantins (UFT), Palmas, TO, Brasil. E-mail: hrgracio@gmail.com.

Odilon Rodrigues de Morais Neto, doutorando em Antropologia pela Universidade de Brasília (UnB) e professor da Universidade Federal do Tocantins (UFT), Miracema do Tocantins, TO, Brasil. E-mail: odilonmorais@uft.edu.br.

André Luis Campanha Demarchi, doutor em Sociologia e Antropologia pela Universidade Federal do Rio de Janeiro (UFRJ) e professor da Universidade Federal do Tocantins (UFT), Porto Nacional, TO, Brasil. E-mail:andredemarchi@gmail.com.

\section{Resumo}

O artigo oferece uma análise comparativa dos dados financeiros provenientes da política pública conhecida como ICMS Ecológico e sua relação com as terras indígenas no estado do Tocantins. A abordagem metodológica se utiliza de pesquisa bibliográfica e documental para analisar comparações de repasses de recursos financeiros advindos do ICMS Ecológico para os municípios de Tocantínia e Tocantinópolis, cujos limites territoriais estão sobrepostos às Terras Indígenas Xerente, Funil 
e Apinajé, habitadas pelos povos Xerente e Apinajé. O trabalho considera os dados públicos disponíveis, os quais são referentes aos repasses do ICMS Ecológico entre os anos de 2011 e 2015 para os municípios. Logo, demonstra-se a importância econômica das terras indígenas para a gestão pública, destacando-se que elas estão longe de ser um obstáculo ao "desenvolvimento" local. Por fim, apontam-se alguns princípios antropológicos balizadores de uma proposta simétrica para as formas de aplicação e gestão dessa política pública.

Palavras-chave: Políticas Públicas. Povos Indígenas. Desenvolvimento. Cerrado.

\section{Abstract}

The article makes a comparative analysis of financial data from the public policy known as Ecological ICMS and how it is related to the Indigenous Lands in the State of Tocantins. The methodology uses literature and documents research to analyze comparisons of financial resources transfers arising from the Ecological ICMS to the municipalities of Tocantínia and Tocantinópolis, which boundaries overlap the Xerente, Funil, and Apinajé indigenous lands, inhabited by the Xerente and Apinajé peoples. When considering the public data available - which refer to the Ecological ICMS transfers from 2011 to 2015 to the municipalities - we demonstrate the economic importance of the indigenous lands to the public management, noting that they are far from being an obstacle to the local "development". Finally, some anthropological benchmark principles for a balanced proposal concerning the forms of implementation and management of this public policy are pointed out.

Keywords: Public Policies. Indigenous Peoples. Development. Cerrado.

\section{Resumen}

El artículo proporciona un análisis comparativo de los datos financieros de la política pública conocida como ICMS Ecológico y su 
relación con las tierras indígenas en el estado de Tocantins. El enfoque metodológico se realiza a través del análisis y comparación de las transferencias de recursos financieros derivados del ICMS Ecológico para los municipios de Tocantínia y Tocantinópolis cuyos límites se superponen a las tierras indígenas Xerente, Funil y Apinajé, habitado por los pueblos Xerente y Apinajé. Al considerar los datos públicos disponibles para las transferencias, del ICMS Ecológico entre los años 2011 y 2015, para los municipios, se demuestra la importancia económica de las tierras indígenas para la gestión pública, observando que están lejos de ser un obstáculo para el "desarrollo" local. Por último, señalan algunos de los patrones de los principios antropológicos, para una propuesta equilibrada de formas de ejecución y gestión de esta política pública.

Palabras clave: Políticas Públicas. Pueblos Indígenas. Desarrollo. Cerrado.

\section{INTRODUÇÃO}

O presente texto descreve e analisa a experiência de implantação do Imposto sobre Circulação de Mercadorias e Serviços Ecológico (ICMS-E) em dois munícipios do estado do Tocantins. Conforme será detalhado nas próximas páginas, o ICMS Ecológico é uma política formatada por lei estadual que regulamenta, com base em termos constitucionais, a divisão dos repasses dos recursos decorrentes do Imposto sobre Circulação de Mercadorias e Serviços - ICMS. Em termos introdutórios, pode-se dizer que o ICMS Ecológico busca premiar os municípios desenvolvedores de políticas diferenciadas nas áreas de proteção ambiental, de saneamento e de promoção do bem-estar social. Nos casos que serão apresentados aqui, o redimensionamento do repasse decorre do fato do território dos municípios de Tocantínia e Tocantinópolis se sobreporem às terras indígenas Xerente e Funil, no caso do primeiro, e Apinajé, no caso do segundo.

Apesar de tratar de dois casos pontuais, ressalta-se que a cena social afetada por essa política é bem mais ampla. A população indígena no estado do Tocantins, atualmente, é formada pelos povos Karajá, Karajá de 
Xambioá, Javaé, Krahô, Krahô-Kanela, Xerente, Apinajé e Avá-Canoeiro. Eles vivem em nove terras indígenas já regularizadas no estado do Tocantins, outras áreas ainda não regularizadas e em zonas urbanas. Esses povos são originários dali, ou seja, sua presença no que é hoje o Tocantins remonta a momentos anteriores ao processo de ocupação não indígena. Além dos já citados, o estado também apresenta contingentes populacionais dos povos Guarani, que vivem entre os Karajá de Xambioá, os Funiô, residentes no norte da terra indígena Apinajé, e as famílias Pakararu, Tuxa e Atikun, originárias do Nordeste brasileiro, residentes de áreas urbanas de distintos municípios do Tocantins. $O$ somatório das superfícies das terras indígenas já regularizadas perfaz 8,55\% da extensão territorial do Tocantins e abarca 15 municípios. Ao todo, são catorze terras indígenas, das quais cinco estão em estudo, ou seja, não estão devidamente regularizadas.

Essas terras indígenas, além de garantir a sobrevivência física e cultural desses povos indígenas, que é sua principal e mais importante atribuição, têm historicamente contribuído com a conservação e preservação do cerrado centro-brasileiro. Tal condição contrapõe-se aos modelos convencionais de exploração dos recursos naturais e ocupação do espaço efetivados pela sociedade nacional. Apesar de seus importantes papéis sociais, históricos e ambientais, essas terras são vistas pelo senso comum como improdutivas, pois estão fora do mercado e vetadas para as práticas produtivas desenvolvimentistas, uma vez que o modelo de exploração e uso dos povos que as habitam se difere daquele efetivado pela sociedade envolvente. Isso gera por parte dos gestores públicos uma compreensão do ICMS Ecológico como política de compensação aos municípios, pois há impossibilidade de exploração econômica das suas extensões territoriais reconhecidas legalmente como terras indígenas. (LOUREIRO, 2002).

Os dados que serão trabalhados nos próximos parágrafos foram obtidos a partir de fontes bibliográficas e documentais. As informações, em sua maior parte, foram sistematizadas e analisadas pelos autores. Desta forma, seguindo a classificação e as orientações de Lakatos e Marconi (2003), foram trabalhados os dados primários e secundários. Neste artigo, não serão tratados os dados obtidos com o contato direto, 
ou, como define a antropologia, por meio de pesquisa etnográfica. Uma pesquisa dessa natureza será objeto de outro trabalho, no qual serão analisados dados etnográficos sobre as percepções dos indígenas em relação ao poder público municipal, no que tange à aplicação dos recursos advindos da arrecadação do ICMS Ecológico. Outro aspecto importante para esta pesquisa, em fase de elaboração, será análise dos pareceres emitidos pela Fundação Nacional do Índio atestando ou não as ações das prefeituras segundo os critérios de pontuação para arrecadação do ICMS Ecológico. Os dados etnográficos estão subjacentes à pesquisa, na medida em que a escolha desse tema se deu em decorrências do envolvimento direto dos autores com os povos originários aqui tratados. Igualmente, salienta-se que a metodologia empregada no estudo tem como propósito sistematizar e comparar dados públicos sobre a importância das terras indígenas para arrecadação dos municípios, cujas áreas territoriais se encontram em situação de sobreposição às terras indígenas no Tocantins. Deste modo, destaca-se qual é, de fato, a contribuição financeira das terras indígenas aos municípios e chama-se atenção para um novo campo de pesquisa a ser explorado sobre as relações interétnicas estabelecidas entre o poder público municipal e os povos indígenas por meio da política pública conhecida como ICMS Ecológico.

Seguindo essa metodologia, o presente artigo tem três objetivos: 1) apresentar um panorama da situação ambiental no Tocantins, salientando os impactos de atividades econômicas nas terras indígenas situadas no estado; 2) demonstrar que os territórios indígenas Xerente e Apinajé não são os principais responsáveis pelo "atraso" no desenvolvimento local, como crê parte da população local e representantes políticos; 3) propor alguns princípios político-antropológicos balizadores de uma proposta simétrica para as formas de aplicação e gestão dessa política pública.

Com vistas a atingir os objetivos propostos, parte-se de uma explicação sumária do ICMS Ecológico e de seus marcos legais, para, em seguida, expor dados referentes à situação territorial do estado do Tocantins, no que tange às terras indígenas e às reservas florestais diante do avanço irrefreável do agronegócio desenvolvimentista. Para desenvolver o argumento de queas terras indígenas não são improdutivas, 
são apresentados valores recebidos pelos municípios tocantinenses por terem os seus territórios sobrepostos aos dos povos indígenas Xerente e Apinajé. Por fim, delineamos uma proposta ética para a gestão inclusiva dessa política pública.

\section{ICMS ECOLÓGICO}

Para compreender o ICMS Ecológico, torna-se importante recorrer ao texto do artigo 158, da Seção VI da Constituição Federal de 1988, que trata da repartição das receitas tributárias entre União, estados e municípios. A Carta Magna trata o tema nos seguintes termos:

Art. 158. Pertencem aos municípios:

I - o produto da arrecadação do imposto da União sobre renda e proventos de qualquer natureza, incidente na fonte, sobre rendimentos pagos, a qualquer título, por eles, suas autarquias e pelas fundações que instituírem e mantiverem;

II - cinquenta por cento do produto da arrecadação do imposto da União sobre a propriedade territorial rural, relativamente aos imóveis neles situados, cabendo a totalidade na hipótese da opção a que se refere 0 art. $153, \S 4^{\circ}$, III;

III - cinquenta por cento do produto da arrecadação do imposto do Estado sobre a propriedade de veículos automotores licenciados em seus territórios;

IV - vinte e cinco por cento do produto da arrecadação do imposto do Estado sobre operações relativas à circulação de mercadorias e sobre prestações de serviços de transporte interestadual e intermunicipal e de comunicação.

Parágrafo único. As parcelas de receita pertencentes aos Municípios, mencionadas no inciso IV, serão creditadas conforme os seguintes critérios:

I - três quartos, no mínimo, na proporção do valor adicionado nas operações relativas à circulação de mercadorias e nas prestações de serviços, realizadas em seus territórios;

II - até um quarto, de acordo com o que dispuser lei estadual ou, no caso dos Territórios, lei federal (Brasil, 2012, p. 99). 
O tópico que interessa particularmente o tema deste trabalho é o IV, pois define que $25 \%$ do produto da arrecadação do ICMS no âmbito de uma unidade federada serão destinados aos seus municípios, assim como os tópicos I e II do parágrafo único, visto que definem, no caso do tópico I, no mínimo, três quartos da proporção tratada no tópico IV serão destinados aos municípios. Essa divisão se dará de acordo com suas arrecadações específicas, ou seja, os municípios de uma dada unidade federada terão parcelas de receita proporcionais a suas arrecadações. A institucionalização de políticas diferenciadas, como é o caso do ICMS Ecológico, torna-se possível em função do tópico II do parágrafo único, que estabelece que até um quarto do valor do ICMS destinados aos municípios de uma unidade federada poderão ser administrados por política definida em lei estadual.

Diante do exposto até aqui, cabem dois destaques. Em primeiro lugar, não há uma determinação constitucional para criação de uma política diferenciada de repasse de recursos advindo do ICMS entre estado e municípios. O texto constitucional abre, tão somente, a possibilidade de tal ocorrência. O segundo ponto se refere ao caráter da política a ser implantada, caso a unidade federada decida pela instituição de parâmetros diferenciados de repasse. A Carta Magna imputa ao estado definir os parâmetros e o caráter da política a ser fomentada com o repasse detalhado no artigo 158 da Constituição Federal de 1988.

Segundo Loureiro (2002), em tese de doutorado dedicada ao tema da "Lei do ICMS Ecológico", o dispositivo legal surge como uma solução financeira para os municípios que abrigavam unidades de conservação ou mananciais de abastecimento de água de interesse público do Paraná, em princípios dos anos 1990. Desde a criação da lei no Paraná, outros estados têm incorporado critérios ambientais como medida para se calcular o valor da arrecadação do ICMS referente aos municípios ${ }^{1}$. 0 autor também observa que:

Nascido sob a égide da compensação, o ICMS Ecológico evoluiu, transformando-se em mecanismo de incentivo à conservação ambiental, o que mais o caracteriza, representando uma promissora
Segundo o site ic m secologico.org. br, os estados que regulamentaram o ICMS Ecológico são: Acre, Amapá Ceará, Goiás, Mato Grosso, Mato Grosso do Sul, Minas Gerais, Paraíba, Paraná, Pernambuco, Piauí, Rio de Janeiro, Rio Grande do Sul, Rondônia, São Paulo e Tocantins. 
alternativa na composição dos instrumentos de política pública para a conservação ambiental no Brasil (LOUREIRO, 2002, p. 53).

Ele também define o ICMS Ecológico como:

[...] um conjunto de critérios de caráter ambiental, usado para estabelecer o percentual que cada município de um determinado Estado tem direito de receber quando do repasse constitucional da quota-parte do Imposto sobre Circulação de Mercadorias e Serviços (ICMS). (LOUREIRO, 2006, p. 01)

Não se trata de um imposto novo, mas de uma nova forma de redistribuir aos municípios a arrecadação estadual. Loureiro chama atenção desde o início para a fragilidade de uma definição do ICMS Ecológico como compensação ambiental aos municípios que têm restrições econômicas, no sentido convencional, tais como regulamentadas pela lógica do ICMS. Em suma, o autor considera o ICMS Ecológico como instrumento técnico de incentivo à preservação ambiental mediante estabelecimento de critérios para o cálculo dos repasses a que os municípios têm direito, evitando, assim, o entendimento do ICMS Ecológico como instrumento de política compensatória.

Segundo o autor, os impostos de origem tributária não são vinculativos, ficando a critério dos gestores municipais entenderem o ICMS Ecológico como uma política efetiva de financiamento de projetos ambientais que visem à conservação da biodiversidade nas áreas municipais. O inciso IV do artigo 167 da Constituição Federal institui que as receitas advindas da arrecadação de impostos não podem ser vinculadas às despesas de programas específicos, como seria o caso se repasses referentes ao ICMS Ecológico estivessem vinculados a programas de preservação ambiental. Uma vez que o estado, por meio do que está disposto no artigo 167, não tem prerrogativa de obrigar legalmente os municípios a vincular suas receitas, a "Lei do ICMS Ecológico" se torna, então um mecanismo de indução para que os municípios, caso queiram aumentar seus índices de participação nas transferências do ICMS, invistam em programas e políticas orientadas para conservação ambiental. 
No Tocantins, o ICMS Ecológico foi instituído com a edição da Lei 1.323, de 4 de abril de 2002, que dispõe sobre os índices integrantes do cálculo da parcela do produto da arrecadação do ICMS pertencente aos municípios. Esse dispositivo legal foi instituído pelo governo do Tocantins, tendo como referência experiências de outros estados, que já haviam criado a "Lei do ICMS Ecológico", principalmente, a partir da experiência paranaense. Diferentemente deste último estado, onde a lei foi criada a partir de uma aliança entre municípios e governo estadual mediado pela assembleia legislativa, no Tocantins, ela foi uma providência do próprio governo estadual (LOUREIRO, 2002). A Lei 1.323 regulamenta critérios ambientais como índices para composição do cálculo a qual os municípios têm direito de receber sobre a arrecadação do ICMS no Tocantins. Essa lei foi regulamentada pelo Decreto n 1.666 de 26 de dezembro de 2002. O anexo único da referida lei adota os seguintes critérios e índices para efeitos de repasses financeiros aos municípios:

Tabela 1 - Critérios para avaliação do ICMS e do ICMS Ecológico no Tocantins

\begin{tabular}{l|c}
\multicolumn{1}{c|}{ Critérios } & Índice de cálculos (\%) \\
\hline Valor adicionado & 75 \\
\hline Quota igual & 8 \\
\hline Número de habitantes & 2 \\
\hline Área territorial & 2 \\
\hline Política Municipal de Meio Ambiente & 2 \\
\hline Unidades de conservação e terras indígenas & 3,5 \\
\hline Controle e combate de queimadas & 2 \\
\hline Conservação do solo & 2 \\
\hline Saneamento básico e conservação da água & 3,5 \\
\hline TOTAL & 100 \\
\hline
\end{tabular}

Fonte: Adaptado pelos autores (TOCANTINS, 2008).

O Decreto n 1.666, de 2002, institui, para cada critério descrito na tabela acima, índices qualitativos e quantitativos que compõem o cálculo da parcela do ICMS pertencente aos municípios. O critério "terras indígenas e 
unidades de conservação" é objeto de avaliação quantitativa nos seguintes aspectos: i) a superfície da terra indígena ou unidade de conservação no município; ii) a categoria de regularização da terra indígena ou da unidade de conservação. Esse critério é contemplado, qualitativamente, por meio de avaliação das ações das prefeituras nas terras indígenas ou nas unidades de conservação de acordo com um questionário de avaliação elaborado pelo Naturatins (Instituto Natureza do Tocantins) e submetido à aprovação do Conselho Estadual de Meio de Ambiente do Tocantins (COEMA/TO), que vigorou entre 2002 e 2012.

Nesse instrumento de avaliação, há um conjunto de 16 questões específicas para terras indígenas. Em linhas gerais, as questões objetivaram mensurar o grau de comprometimento dos recursos com o incentivo e apoio à preservação ambiental (TOCANTINS, 2017). Até 2013, com a publicação da Resolução $n^{\circ} 40$ da COEMA/TO, os documentos comprobatórios das ações municipais realizadas em terras indígenas eram avaliados exclusivamente pelo Naturatins e pelo Instituto de Desenvolvimento Rural do Tocantins (Ruraltins).

Salienta-se que a construção desse questionário de avaliação qualitativa das ações municipais nas terras indígenas foi de inteira responsabilidade dos órgãos estaduais envolvidos na regulamentação e aplicação do ICMS Ecológico no Tocantins. Isto é, em seu processo de construção não houve nenhum diálogo com os povos indígenas, tampouco com as entidades indigenistas governamentais e não governamentais que atuam a seu favor. A ausência do órgão indigenista oficial e, principalmente, dos povos indígenas, dá respaldo à afirmação de que a implantação do ICMS Ecológico no Tocantins, e de seus instrumentos de avaliação para efeitos do cálculo dos repasses, violou a Convenção 169 da Organização Internacional do Trabalho. Cabe destacar que a convenção, da qual o Brasil é signatário, trata, entre outros temas, da obrigatoriedade de participação dos povos indígenas no processo de elaboração de políticas públicas a eles relacionadas. Ademais, é digno de nota o total desconhecimento dos povos indígenas sobre o ICMS Ecológico. Eles ficam alheios tanto ao controle social das informações fornecidas pela prefeitura à Naturatins quanto ao preenchimento dos relatórios de atividades exigidas como critérios de composição do cálculo do ICMS Ecológico. 
Em 2013, o Conselho Estadual do Meio Ambiente, na resolução nº 40, de 27 de agosto, aprovou reformulações no questionário de avaliação qualitativa necessário para o cálculo da parcela do ICMS pertencente aos municípios. Nessa reformulação, houve uma redução das questões integrantes da avaliação, condensando-as em apenas quatro:

2.1. Quanto ao apoio do Município ao desenvolvimento da temática ambiental junto à comunidade indígena:

2.1.1 - 0 município apoia e/ou executa: ( ) ações e/ou atividades educativas, diretamente ou em parceria - 10 pontos; ( ) práticas agroecológicas em parceria com o órgão de extensão rural e entre outras instituiç̧ões - 30 pontos

Documentos comprobatórios: relatório de atividades realizadas contendo fotos datadas, lista de presença, folders, termo de cooperação técnica, etc

2.1.2. Existem projetos de preservação e conservação ambiental com apoio da prefeitura na comunidade indígena? () Não - 0 pontos () Sim - 10 pontos

Documentos comprobatórios: fotos, cópia do projeto, declaração da FUNAI (atestando a existência do projeto na Terra Indígena).

2.1.3 - A prefeitura promove atividades de prevenção e combate a queimadas na terra indígena? ( ) treinamentos -5 pontos ( ) Aceiros - 5 pontos ( ) disponibilização de brigadas - 10 pontos () fornecimento de equipamentos de combate e EPI - 10 pontos

Documentos comprobatórios: relatório de atividade realizada contendo fotos datadas, lista de presença, folders, certificados, material educativo distribuído em ações educativas/preventivas, notas fiscais e outros.

2.1.4 - A prefeitura faz coleta de resíduos sólidos e desenvolve atividades educativas? () de $25 \%$ a $50 \%$ das aldeias - 5 pontos () de $50 \%$ a $75 \%$ das aldeias - 10 pontos () acima de $75 \%$ das aldeias 20 pontos

Documentos comprobatórios: fotos, declaração da FUNAI (atestando a existência do projeto na Terra Indígena). (TOCANTINS, 2013)

Outra alteração merece destaque na resolução $n^{\circ} 40$ de 2013 da COEMA/TO. Ela inclui a participação do órgão indigenista 
oficial, a Fundação Nacional do Índio (Funai), em duas das questões apresentadas. A fundação fica responsável por atestar a comprovação das ações encaminhadas pela gestão pública municipal no que se refere à elaboração do questionário de avaliação qualitativa do ICMS Ecológico. A inclusão da Funai, embora constitua um avanço do controle social dessa política pública ambiental, tardiamente incorporada, não garante, ainda, a participação indígena no acompanhamento da execução e aplicação do ICMS Ecológico pelas prefeituras.

Antes da análise dos repasses do ICMS Ecológico às prefeituras de Tocantínia e Tocantinópolis, bem como suas consequências para as terras indígenas Xerente e Apinajé, é preciso retornar ao tema das terras indígenas, das unidades de conservação e do atual estado das políticas de conservação e preservação no estado do Tocantins.

\section{A QUESTÃO AMBIENTAL NO TOCANTINS}

Segundo dados disponíveis na página do Instituto Socioambiental (2015), um número significativo de ameaças ambientais e sociais pairam sobre as terras tradicionalmente ocupadas no Tocantins e suas populações. Em índices variáveis, o desmatamento afeta todas as áreas e seus entornos. Pressões exercidas sobre os recursos naturais decorrentes de exploração ilegal de não indígenas também se mostram presentes. A ênfase no modelo econômico pautado no fomento do agronegócio representa uma ameaça significativa em função de seus impactos sociais e ambientais, que se manifestam de diversas formas: contaminação dos recursos hídricos; diminuição das espécies nativas de fauna e flora (pelo isolamento e pela supressão da cobertura vegetal nativa); aumento dos contingentes populacionais; adensamento das infraestruturas necessárias às atividades, tais como estradas, ferrovias entre outras ocorrências; ações comprometedoras dos recursos naturais e o seu acesso pelas populações originárias.

Todavia, uma das consequências diretas desse alinhamento econômico se encontra no plano político e se manifesta pela pressão contrária ao reconhecimento dos direitos fundiários dos povos originários. Entre os vários projetos em tramitação no Poder Legislativo, visando 
inibir os direitos dos povos originários, destaca-se a Proposta de Emenda à Constituição - PEC 215/2000, de autoria do Deputado Federal Almir Morais Sá. Essa proposta objetiva incluir, entre as competências exclusivas do Congresso Nacional, a aprovação de demarcação das terras tradicionalmente ocupadas pelos índios, retirando do poder executivo essa prerrogativa. A PEC 215/2000, se aprovada, terá impactos sobre todas as terras indígenas que aguardam pela regularização fundiária.

As decorrências do modelo de ocupação exercido pela sociedade nacional são amplas e profundas e podem ser observadas em várias conjunturas e sob distintos prismas. O Instituto Chico Mendes de Conservação da Biodiversidade (ICMBIO), por exemplo, informa que a cada segundo morrem atropelados nas rodovias e estradas brasileiras 15 animais silvestres. Essa situação gera 1,3 milhões de mortes por dia e 475 milhões por ano (Brasil, 2015a). A avaliação das mortes de animais silvestres por atropelamento no Tocantins poderia ser um caminho de tratamento do tema aqui proposto, uma vez que o estado possui uma considerável malha rodoviária e comporta uma das mais importantes rodovias do Brasil, a BR-153. É importante lembrar que os gestores e políticos do estado acalentam projetos rodoviários que, caso efetivados, terão significativos impactos ambientais e sociais, como é o caso da proposta de pavimentação de uma rodovia cruzando a llha do Bananal no sentido leste para o oeste. Também se deve destacar que os impactos das rodovias não se restringem tão somente à morte de animais. Não obstante prestem serviços imprescindiveis a toda população, a malha rodoviária também é o principal vetor de ocupações irregulares, seguidas de desmatamentos, exploração ilegal de recursos naturais e todas as consequências atreladas às frentes de expansão da sociedade nacional. Assim como o isolamento biológico de populações (animais e plantas) e o surgimento de núcleos urbanos sem o devido planejamento acarretam um grande número de impactos sociais, sanitários e ambientais.

Outro enfoque possível são os impactos gerados pelas hidrelétricas. Somente o rio Tocantins comporta as usinas hidrelétricas: de Cana Brava e Serra da Mesa, localizadas em seu alto curso ainda no estado de Goiás; a de São Salvador, entre os municípios tocantinenses de São Salvador do 
Tocantins e Paranã; a de Luiz Eduardo Magalhães, situada nos municípios Miracema do Tocantins e Lajeado, ambos no estado do Tocantins; a do Estreito, localizada na divisa entre o Tocantins e o Maranhão; e, por fim, a de Tucuruí, localizada no sul do Pará. A importância da energia elétrica é inquestionável no mundo moderno. Por outro lado, as hidrelétricas também geram graves e intensos prejuízos sociais, fundiários, econômicos e ambientais.

Na longa lista de possibilidades, podem-se citar as atividades: mineração, pesca, caça predatória, corte e venda de madeira ilegal, queimadas, especulação imobiliária e tantas outras atividades que são vistas por alguns como positivas, mas comprometem a qualidade de vida da maioria da população.

Apesar de as possibilidades listadas acima, optamos trabalhar com o tema desmatamento por entendê-lo como indicativo de grande parte dos eventos citados. Além disso, o desmatamento decorre da forma de ocupação e do modelo de exploração dos recursos naturais efetivados pela sociedade nacional, sendo, portanto, fruto de ações localizadas em termos históricos, sociais, culturais e econômicos. 0 artigo pretende evidenciar 0 desmatamento como índice de uma forma específica de ocupação. Para tanto, basta simplesmente comparar as decorrências das ocupações dos povos originários e as das frentes de expansão da sociedade nacional. Durante os 12 mil anos que antecederam a colonização e formação do Brasil, nenhuma prática humana provocou a devastação verificada hoje.

Para iniciar o tratamento do assunto, torna-se importante destacar a visão de Silva (2007), com base em dados produzidos pelo IBGE. Há 9\% do estado do Tocantins formados pelo bioma Amazônico. Os demais 91\% do território são formados pelo Cerrado. Essa informação apresenta um primeiro impasse a ser superado. A principal ferramenta de avaliação de desmatamento na Amazônia Legal é o Projeto de Monitoramento do Desmatamento na Amazônia Legal por Satélite (PRODES). Esse projeto é administrado pelo Instituto Nacional de Pesquisas Espaciais (INPE) e voltase à publicação anual das taxas de desmatamento na Amazônia Legal, configurando-se como uma das principais ferramentas do poder público 
no tratamento do tema. Todavia, a ferramenta só registra desmatamentos incidentes no bioma amazônico, não computando dados relativos a outros biomas.

O PRODES registra um índice de "não floresta" no estado do Tocantins de $84,85 \%$, ou seja, em praticamente $85 \%$ da extensão do estado o sistema não é capaz de dizer se houve ou não desmatamento. A título comparativo se destaca que o estado do Acre possui um índice de "não floresta" de 0,04\%, ou seja, contando com boas imagens e baixa incidência de nuvens, o PRODES pode detectar desmatamentos em 99,96\% de toda extensão territorial do Acre. Os demais estados da Amazônia Legal apresentam os seguintes índices de "não floresta": Amazonas, 3,07\%; Amapá, 17,92\%; Maranhão, 42,96\%; Mato Grosso, 42,76\%; Pará, 5,88\%; Rondônia, 10,25\%; e Roraima, 27,06\%.

O PRODES, tendo como referência o ano de 2013, informa que 0 estado do Tocantins possui um acúmulo de $30.421 \mathrm{~km}^{2}$ de área desmatada, o que representa $10,90 \%$ de toda a extensão do estado. Todavia, o sistema só opera sobre $15,15 \%$ de toda a sua extensão territorial. Assim, pouco mais de dois terços da área monitorada no estado encontra-se desmatada. Outra informação importante corresponde à extensão desmatada no Tocantins, que abarca $75,63 \%$ de toda a área de floresta do estado².

O Plano de Ação para Prevenção e Controle do Desmatamento na Amazônia Legal (PPCDAm) entrou em atividade em 2004 com objetivo de conter o sistemático índice de desmatamento da Amazônia Legal. Segundo o relatório de avaliação do PPCDAm, dois elementos foram essenciais para a positiva diminuição dos índices de desmatamento da cobertura florestal da região verificados a partir de 2004: monitoramento e controle (BRASIL, 2013). Nesse sentido, a peça técnica enfatiza a importância do PRODES como ferramenta que permite um monitoramento anual e seguro das taxas de desmatamento e por favorecer, com sua agilidade e segurança no tratamento dos dados, a construção de políticas públicas voltadas ao controle da supressão da cobertura vegetal das áreas de florestas. Todavia, apesar de o Tocantins pertencer à Amazônia Legal, um dos principais sistemas de monitoramento de desmatamentos é praticamente ineficaz para o estado.
2 Disponivel em: <http:// www.obt.inpe.br/prodes/ index.php>. Acesso em: 19 dez. 2016. 
Embora não possuam a mesma periodicidade e agilidade do PRODES, os órgãos ambientais também produzem informações sobre o desmatamento no Cerrado. Segundo relatório técnico do Ministério do Meio Ambiente (BRASIL, 2011), o bioma Cerrado ocupa $2.039 .386 \mathrm{~km}^{2} \mathrm{e}$ acumulou, até o ano de 2009, uma extensão desmatada de $983.348 \mathrm{~km}^{2}$, ou seja, 48,21\%. Segundo a mesma fonte, em termos históricos o Cerrado teve $43,6 \%$ de sua área desmatada até o ano de 2002, índice em ascensão para 47,8\% em 2008. Entre os anos de 2009 e 2010, o bioma registrou um desmatamento da ordem de $6.469 \mathrm{~km}^{2}$, ou 0,31\% de sua área total. A tabela abaixo mostra como a extensão desmatada distribui-se entre as unidades federadas abarcadas pelo bioma. Tocantins figura em terceiro lugar, registrando uma taxa de desmatamento 0,39\% de cerrado entre os anos de 2009 e 2010.

Tabela 2 - Uso antrópico do Bioma Cerrado entre os anos de 2009-2010

\begin{tabular}{|c|c|c|c|c|}
\hline Estado & UF & $\begin{array}{c}\text { Área do estado coberta } \\
\text { pelo bioma Cerrado } \\
\mathrm{Km}^{2}\end{array}$ & $\begin{array}{c}\text { Uso } \\
\text { antrópico } \\
2009-2010 \\
\mathrm{Km}^{2} \\
\end{array}$ & $\%$ \\
\hline Maranhão & $\mathrm{MA}$ & 212.092 & $1.583,77$ & 0,75 \\
\hline Piauí & $\mathrm{Pl}$ & 93.424 & 980,27 & 1,05 \\
\hline Tocantins & TO & 252.799 & 979,74 & 0,39 \\
\hline Mato Grosso & MT & 358.837 & 769,89 & 0,21 \\
\hline Bahia & $\mathrm{BA}$ & 151.348 & 718,05 & 0,47 \\
\hline Goiás & $\mathrm{GO}$ & 329.595 & 593,58 & 0,18 \\
\hline Minas Gerais & MG & 333.710 & 524,3 & 0,16 \\
\hline Mato Grosso do Sul & MS & 216.015 & 310,36 & 0,14 \\
\hline Distrito Federal & DF & 5.802 & 4,8 & 0,08 \\
\hline São Paulo & $\mathrm{SP}$ & 81.137 & 3,26 & 0,05 \\
\hline Paraná & PR & 3.742 & 1,08 & 0,03 \\
\hline Rondônia & $\mathrm{RO}$ & 452 & 0,06 & 0,01 \\
\hline Total & & 2.038 .953 & $6.469,16$ & 0,32 \\
\hline
\end{tabular}

Fonte: Brasil (2011).

A imagem abaixo complementa os dados anteriores, permitindo a verificação da distribuição do bioma Cerrado ao longo do território 
nacional. O mapa (Figura 1) apresenta trechos, onde a cobertura vegetal foi suprimida, eáreas que até o ano de 2010 ainda contavam com a cobertura nativa. Percebe-se a supressão de grande parte do cerrado das regiões Centro-Oeste e Sudeste. Verifica-se também que a área mais preservada do bioma encontra-se no leste da Amazônia Legal e no Nordeste.

\section{Figura 1 - Desmatamento do bioma Cerrado até 2010}

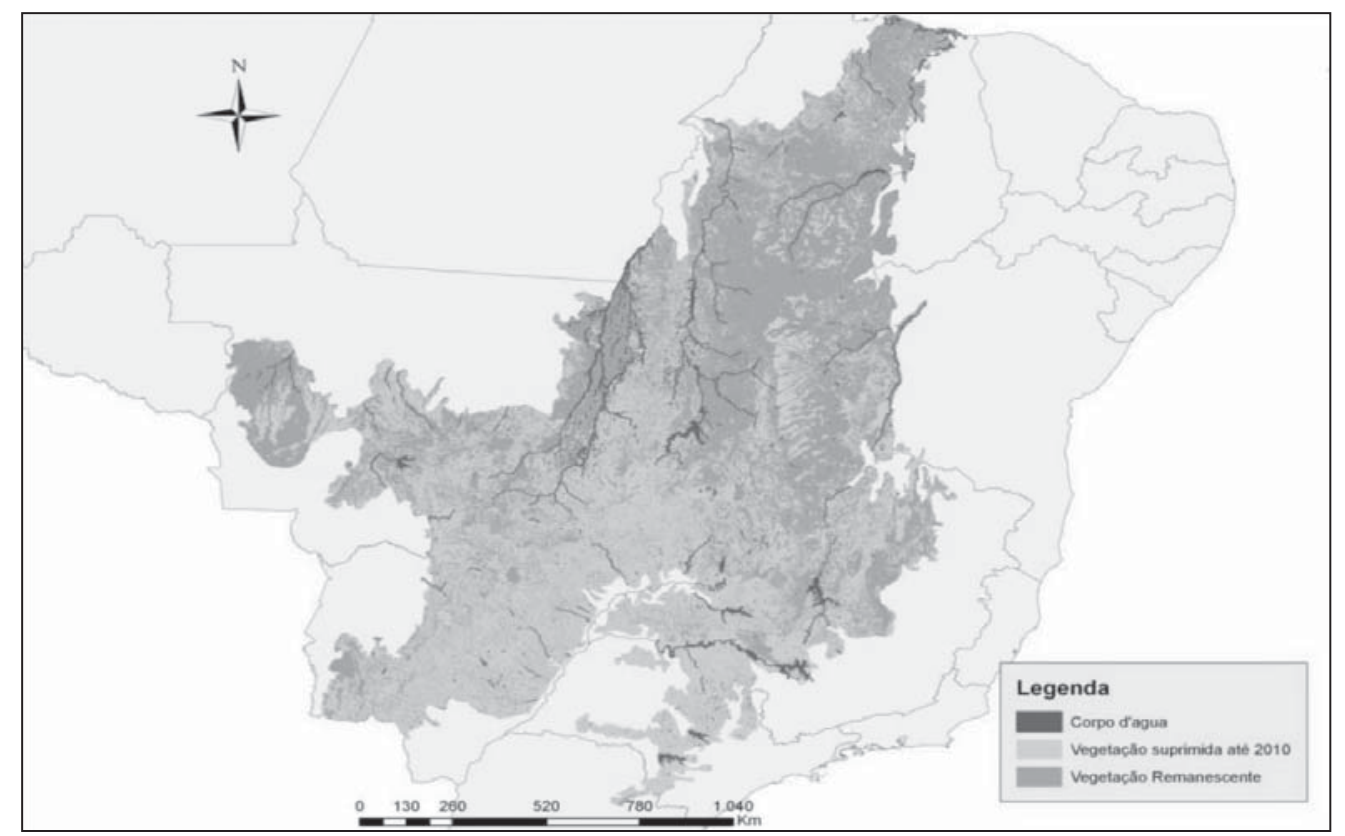

Fonte: Brasil (2011).

Para finalizar a abordagem sobre o Cerrado, cabe destacar a consonância das informações já apresentadas sobre o Tocantins. O relatório do Ministério do Meio Ambiente (BRASIL, 2011) informa que o bioma possui apenas $7,44 \%$ de sua área protegida por unidades de conservação, federais, estaduais e municipais, sendo que somente aproximadamente $2,91 \%$ do bioma é abarcado por unidades de conservação de proteção integral.

Antes de avançar para outros temas, destacam-se os diagnósticos produzidos pelo mesmo ministério (BRASIL, 2009). Eles relacionam o desmatamento do Cerrado à expansão de lavouras para: produção de grãos, pecuária, mineração e exploração do carvão vegetal.

Diante deste quadro preocupante caracterizado pelo avanço do desmatamento sobre as regiões onde o bioma Cerrado ainda encontra 
espaço de preservação, relata-se o registro da publicação do Decreto $n^{\circ}$ 8.447, de 6 de maio de 2015. 0 decreto dispõe sobre o Plano de Desenvolvimento Agropecuário do Matopiba, abrangendo os estados do Maranhão, Tocantins, Piauí e Bahia. A sigla que denomina a política refere-se às letras iniciais dos nomes de cada um dos estados de sua área de abrangência. $O$ artigo $1^{\circ}$ desse decreto define a política nos seguintes termos:

Art. $1^{\circ}$ Este Decreto dispõe sobre o Plano de Desenvolvimento Agropecuário do Matopiba - PDA-Matopiba, que tem por finalidade promover e coordenar políticas públicas voltadas ao desenvolvimento econômico sustentável fundado nas atividades agrícolas e pecuárias que resultem na melhoria da qualidade de vida da população.

$\S 1^{\circ} \mathrm{O}$ PDA-Matopiba será publicado por ato do Ministro de Estado da Agricultura, Pecuária e Abastecimento e definirá os municípios dos estados da Bahia, Maranhão, Piauí e Tocantins incluídos na sua área de abrangência.

$\S 2^{\circ}$ O PDA-Matopiba orientará programas, projetos e ações federais relativos a atividades agrícolas e pecuárias a serem implementados na sua área de abrangência e promoverá a harmonização daqueles já existentes, observadas as seguintes diretrizes:

I - desenvolvimento e aumento da eficiência da infraestrutura logística relativa às atividades agrícolas e pecuárias;

II - apoio à inovação e ao desenvolvimento tecnológico voltados às atividades agrícolas e pecuárias; e

III - ampliação e fortalecimento da classe média no setor rural, por meio da implementação de instrumentos de mobilidade social que promovam a melhoria da renda, do emprego e da qualificação profissional de produtores rurais. (BRASIL, 2015b).

Segundo nota técnica da Empresa Brasileira de Pesquisa Agropecuária (Embrapa), o Matopiba "é uma região do Norte/Nordeste brasileiro marcada pela expansão das atividades agrícolas em áreas de Cerrado, baseada em tecnologias de alta produtividade" (EMBRAPA, 2014a, p. 2). Parte dos números que ilustra esse avanço está apresentada no quadro abaixo, disponibilizado em informativo da Embrapa (2014b): 
Tabela 3 - Produção de soja e grãos nos estados do MATOPIBA em 1993 e 2011

\begin{tabular}{l|c|c|c|c}
\hline \multirow{2}{*}{ Estado } & \multicolumn{2}{|c|}{ Produção de soja (t) } & \multicolumn{2}{c}{ Produção de grãos (t) } \\
\cline { 2 - 5 } & $\mathbf{1 9 9 3}$ & $\mathbf{2 0 1 1}$ & $\mathbf{1 9 9 3}$ & $\mathbf{2 0 1 1}$ \\
\hline Maranhão & 84.012 & 1.511 .321 & 734.209 & 2.508 .849 \\
\hline Tocantins & 31.782 & 1.153 .902 & 476.243 & 1.987 .421 \\
\hline Piauí & 4.745 & 1.081 .643 & 114.569 & 1.736 .335 \\
\hline Bahia & 648.551 & 3.279 .429 & 1.179 .531 & 6.271 .497 \\
\hline \multicolumn{1}{c|}{ Total } & 769.090 & 7.026 .295 & 2.504 .552 & 12.504 .102 \\
\hline
\end{tabular}

Fonte: Embrapa (2014a).

Os dados acima indicam a produção geral de soja e grão entre os anos de 1993 e 2011. No período em referência, a produção de soja teve um acréscimo da ordem de $813,48 \%$, ao passo que a produção de grãos de um modo geral cresceu 399,25\%. Variações percentuais significativas são observadas em toda a tabela, indicando, entre outros fatores, que atividade e foco são relativamente novos na região e, potencialmente, tendem a crescer. Esse é de fato o cerne do Matopiba.

Ainda segundo a nota técnica da Embrapa (2014a), o Matopiba tem uma extensão de 73 milhões de hectares, dos quais 91\% são áreas de Cerrado, 7,3\% do bioma amazônico e 1,7\% de Caatinga. Esses percentuais deixam claro que o foco do Matopiba é a exploração econômica do Cerrado. A Figura 2 detalha a cobertura do Matopiba, destacando os biomas implicados com a política, assim como sua faixa de incidência na Amazônia Legal. 
Figura 2 - Incidência do Matopiba nos biomas: Amazônia, Cerrado e Caatinga

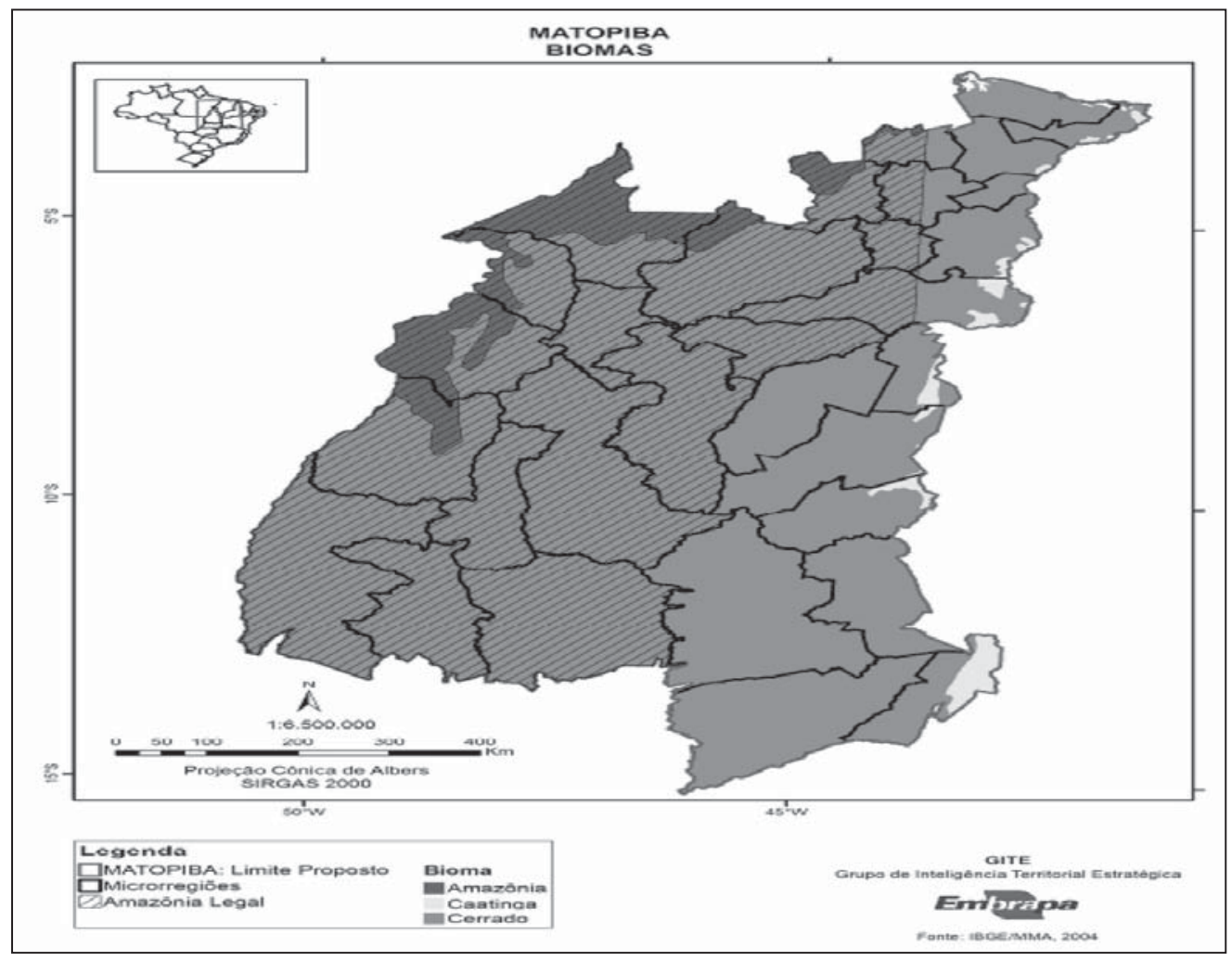

Fonte: Embrapa (2014a).

Os números de produtividade referentes ao período de 1993 a 2011, já expostos, indicam parte das atividades responsáveis por promover o aumento vertiginoso dos índices de desmatamento na região em foco. Com o fomento de políticas favorecedoras das atividades agrícolas na região promovidas pelo Matopiba, a tendência é que tanto os números relativos à produção quanto os relativos ao desmatamento aumentem ainda mais.

Os dados e considerações acima indicam a necessidade de construção de políticas públicas capazes de administrar os danos advindos do processo de desenvolvimento. Faz-se necessário instituir uma agenda que promova uma convivência entre os direitos dos povos indígenas e das outras populações tradicionais, conciliando os interesses econômicos e políticos que fomentam o modelo de desenvolvimento. Neste momento, pode-se retornar ao ponto central do presente artigo e apresentar alguns dados que retratam experiências práticas do ICMS Ecológico no Tocantins. 


\section{QUANTO VALEM AS TERRAS INDÍGENAS XERENTE, FUNIL E APINAJÉ PARA ARRECADAÇÃO DO ICMS ECOLÓGICO?}

O estado do Tocantins abriga um caso paradigmático quando discute o tema da contribuição das terras indígenas para a conservação ambiental e na arrecadação do ICMS Ecológico. Em contraposição ao modelo de ocupação do território pautado no aumento vertiginoso do desmatamento e da degradação ambiental, as terras tradicionalmente ocupadas pelos povos indígenas têm se constituído como pequenas ilhas de biodiversidade do Cerrado cercadas por projetos de monocultura. Com efeito, isso tem gerado, para alguns municípios tocantinenses, uma receita importante na arrecadação do ICMS. Trataremos aqui de dois casos paradigmáticos, começando pelos Xerente em Tocantínia e passando, então, para os Apinajé em Tocantinópolis, Maurilândia e Cachoeirinha. Os dados financeiros sistematizados nesta pesquisa referentes aos repasses do ICMS Ecológico entre os anos de 2011 e 2015 (período em que está disponível a consulta para estes municípios) demonstram que os territórios indígenas acima mencionados estão longe de ser os principais responsáveis pelo "atraso" no desenvolvimento local, como querem fazer crer parte da população local e representantes políticos.

\subsection{Os Xerente em Tocantínia}

O território indígena Xerente, composto pelas terras indígenas Xerente e Funil, está situado na microrregião central do Tocantins, a cerca de $70 \mathrm{~km}$ de Palmas. A área indígena do Xerente foi delimitada pelo Decreto 71.107, de 14 de setembro de 1972, demarcada pelo Decreto 76.999, de 8 de janeiro de 1976, e homologada pelo Decreto 97.838, de 16 de junho de 1989, com extensão de 167.542,105 hectares. A área indígena Funil, por sua vez, foi delimitada pela Portaria 1.187/82, de 24 de fevereiro de 1982, e homologada pelo Decreto 269, de 29 de outubro de 1991, com extensão de 15.703,797 hectares. Totalizando 183.245,902 hectares, estas áreas indígenas fazem parte do município de Tocantínia, sobrepondo-se a ele cerca de 70\% de seu território.

De acordo com dados da Secretaria da Fazenda do Estado do Tocantins, Tocantínia foi o município que obteve o maior repasse 
referente ao ICMS Ecológico entre todos os municípios do estado do Tocantins entre 2011 e 2014.

Tabela 3 - Repasses do ICMS e ICMS Ecológico em Tocantínia

\begin{tabular}{c|c|c|c}
\hline ANO & $\begin{array}{c}\text { ICMS -VA/ } \\
\text { IBGE }\end{array}$ & ICMS Ecológico & $\begin{array}{c}\text { Total (ICMS } \\
+ \text { ICMS-E) }\end{array}$ \\
\hline 2011 & $471.883,55$ & $1.849 .805,01$ & $2.321 .688,56$ \\
\hline 2012 & $502.807,84$ & $2.083 .303,44$ & $2.586 .111,28$ \\
\hline 2013 & $548.381,74$ & $2.797 .681,66$ & $3.346 .063,40$ \\
\hline 2014 & $625.598,42$ & $3.614 .816,07$ & $4.240 .414,49$ \\
\hline 2015 & $440.614,94$ & $4.170 .714,10$ & $4.611 .329,04$ \\
\hline
\end{tabular}

Fonte: Secretaria da Fazenda do Estado do Tocantins - SEFAZ/TO (2017).

Analisando-se a evolução dos repasses do ICMS Ecológico entre 2011 e 2014 para Tocantínia, logo se percebe um grande impacto nas receitas municipais. Em 2011, o município recebeu o repasse de $\mathrm{R} \$$ 1.849.805,01. Em 2012, recebeu $\mathrm{R} \$ 2.083 .303,44$. Em relação aos dois primeiros anos é perceptível o aumento de aproximadamente $22 \%$. No ano de 2013, o mesmo município recebeu $\mathrm{R} \$ 2.797 .681,66$, seguindo

3 Segundo manual da Secretaria da Fazenda do estado do Tocantins, "O Valor Adicionado (VA), resultante do movimento econômico do município, é apurado pela relação percentual entre o Valor Adicionado de cada município e o Valor Adicionado total do estado, referente às operações relativas à circulação de mercadorias e das prestações de serviços de transportes intermunicipal e interestadual e de comunicação, realizadas ou cuja prestação tenha iniciado em seus respectivos territórios". A fórmula para o cálculo do Valor Adicionado é ainda função da relação percentual entre a quantidade de habitantes do município e a quantidade total de habitantes do estado, segundo dados fornecidos pelo Instituto Brasileiro de Geografia e Estatística - IBGE. um aumento de $25 \%$, em relação ao ano anterior. Em 2014, Tocantínia arrecadou $\mathrm{R} \$ 3.614 .816,07$, computando um aumento de mais de $22 \%$ em relação ao ano anterior. Em 2015, a arrecadação foi de R \$ 4.170.714,10.

\section{Gráfico 1 - Repasses do ICMS Ecológico ao município de Tocantínia}

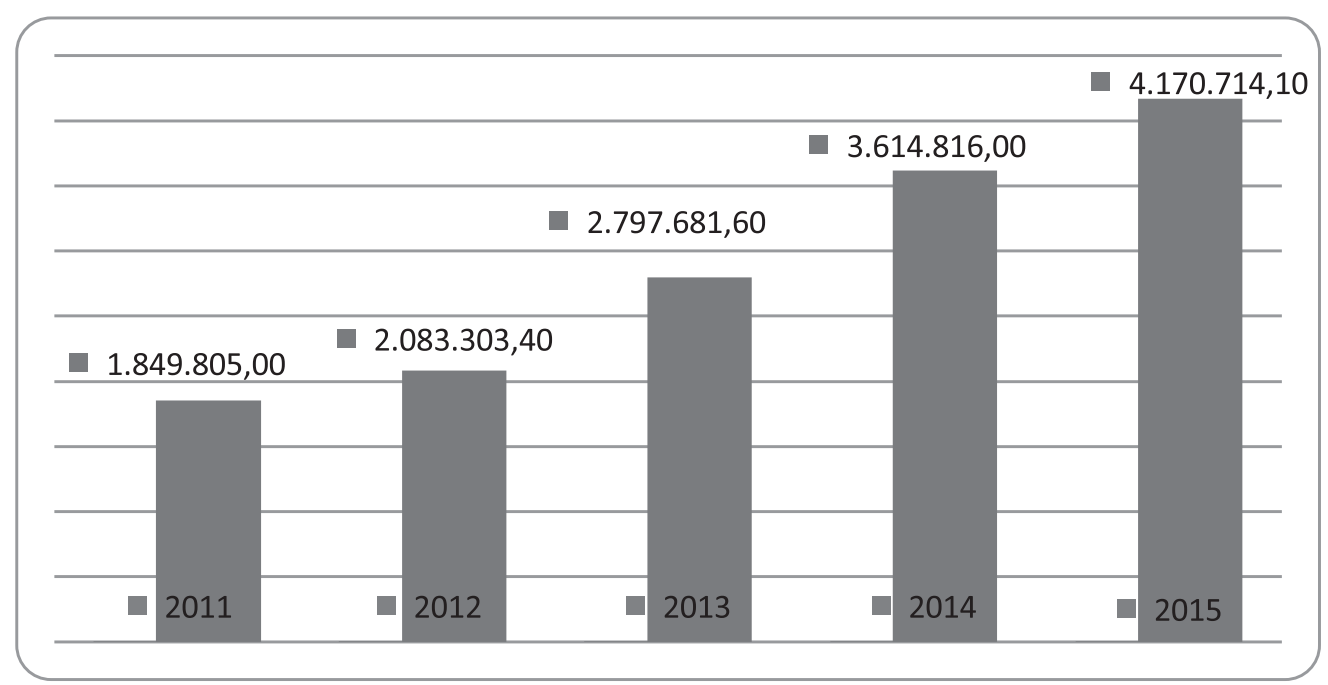

Fonte: Morais (2016). 
O gráfico apresenta a comparação entre os repasses financeiros referentes ao ICMS e o ICMS Ecológico, logo fica evidente o grau de dependência do município de Tocantinía em relação ao critério ambiental - cerca de 80\% da arrecadação do município é oriunda do ICMS Ecológico, superando critérios estritamente econômicos. Os dados da Secretaria da Fazenda do estado do Tocantins apontam que o quesito "terras indígenas" foi o que mais pesou na arrecadação do ICMS Ecológico em Tocantínia.

\subsection{OS APINAJÉ EM TOCANTINÓPOLIS, MAURILÂNDIA E CACHOEIRINHA}

Segundo Bandeira (2014), a terra indígena Apinajé está situada na região do bico do papagaio, no extremo norte do estado do Tocantins. Conforme dados informados pelo autor, 59\% da área municipal de Tocantinópolis é território indígena. Maurilândia tem $70 \%$ de sua área sobreposta ao território Apinajé. Cachoeirinha, por sua vez, tem $41 \%$ de sua área municipal para uso exclusivo dos Apinajé. São Bento do Tocantins, enfim, tem a menor porção de seu território incidindo no território indígena, cerca de $18 \%$.

Figura 3 - Mapa da terra indígena Apinajé e sua sobreposição aos municípios tocantinenses

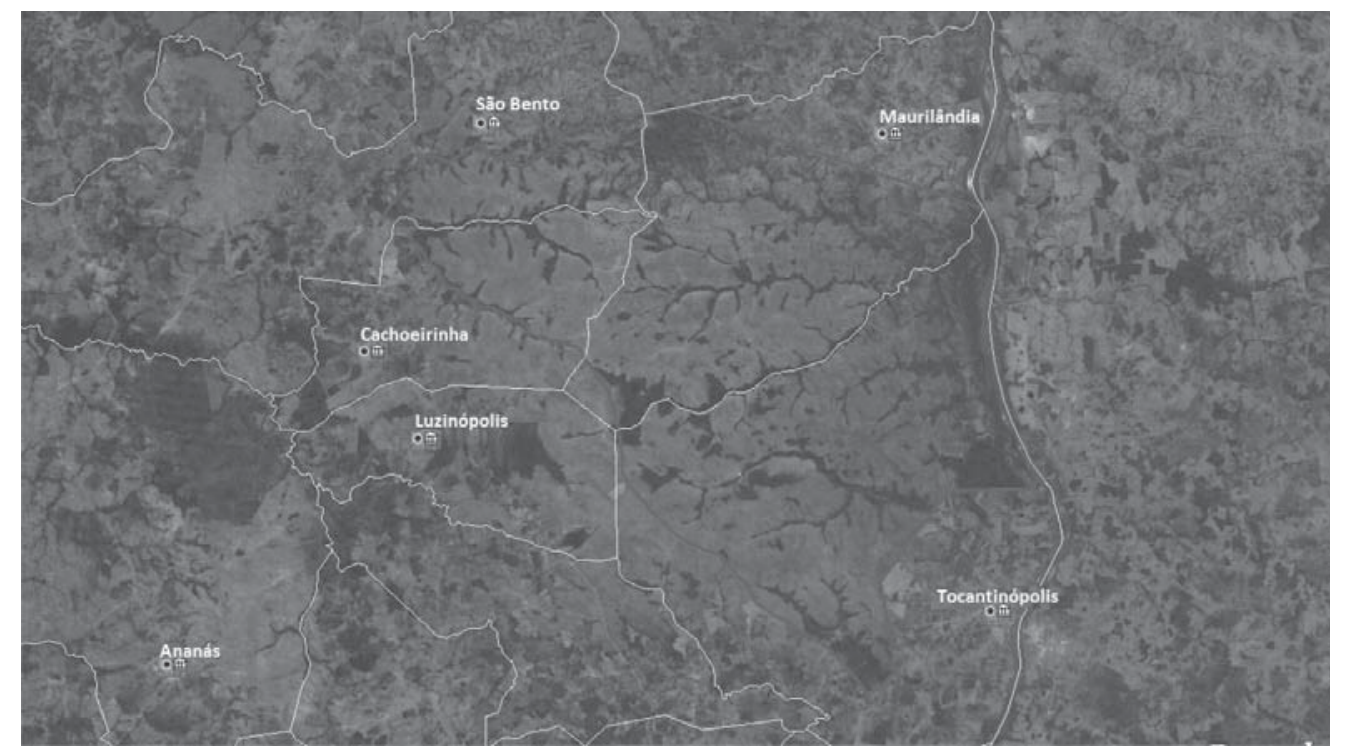

Fonte: Bandeira (2014). 
Tabela 4 - Dados relativos à sobreposição da terra indígena Apinajé aos municípios tocantinenses

\begin{tabular}{l|r|r|r|r}
\hline \multicolumn{1}{c|}{ CIDADE } & $\begin{array}{c}\text { ÁREA DO } \\
\text { MUNICÍPIO }\end{array}$ & $\begin{array}{c}\text { ÁREA } \\
\text { INDÍGENA }\end{array}$ & $\begin{array}{c}\text { No DE HAB. } \\
\text { MUNICÍPIO }\end{array}$ & $\begin{array}{c}\text { N DE HAB. } \\
\text { INDIIGENA }\end{array}$ \\
\hline TOCANTINÓPOLIS & $1.077,073 \mathrm{~km}^{2}$ & $640,58 \mathrm{~km}^{2}$ & 22.619 & 1676 \\
\hline MAURILANDIA & $738,105 \mathrm{~km}^{2}$ & $523,89 \mathrm{~km}^{2}$ & 3.154 & 146 \\
\hline CACHOEIRINHA & $352,345 \mathrm{~km}^{2}$ & $145,38 \mathrm{~km}^{2}$ & 2.148 & 1 \\
\hline SÃO BENTO & $1.105,901 \mathrm{~km}^{2}$ & $129,92 \mathrm{~km}^{2}$ & 4.608 & 29 \\
\hline
\end{tabular}

Fonte: Bandeira(2014).

Percebe-se um grande impacto nas receitas municipais, quando se analisa a evolução dos repasses do ICMS entre 2011 e 2014, em Tocantinópolis. Em 2011, o município arrecadou R\$ 534.114,15. Em 2012, recebeu $R \$ 1.233 .803,26$. 0 aumento de 131\% é perceptível em relação aos dois primeiros anos. No ano de 2013, o mesmo município recebeu $R \$ 2.194 .909,63$, seguindo um aumento de 77,90\%, em relação ao ano anterior. Em 2014, Tocantinópolis arrecadou $\mathrm{R} \$$ 4.251.213,24, computando um aumento de mais de $200 \%$ em relação ao ano anterior.

\section{Gráfico 2 - Repasses do ICMS Ecológico ao município de Tocantinópolis}

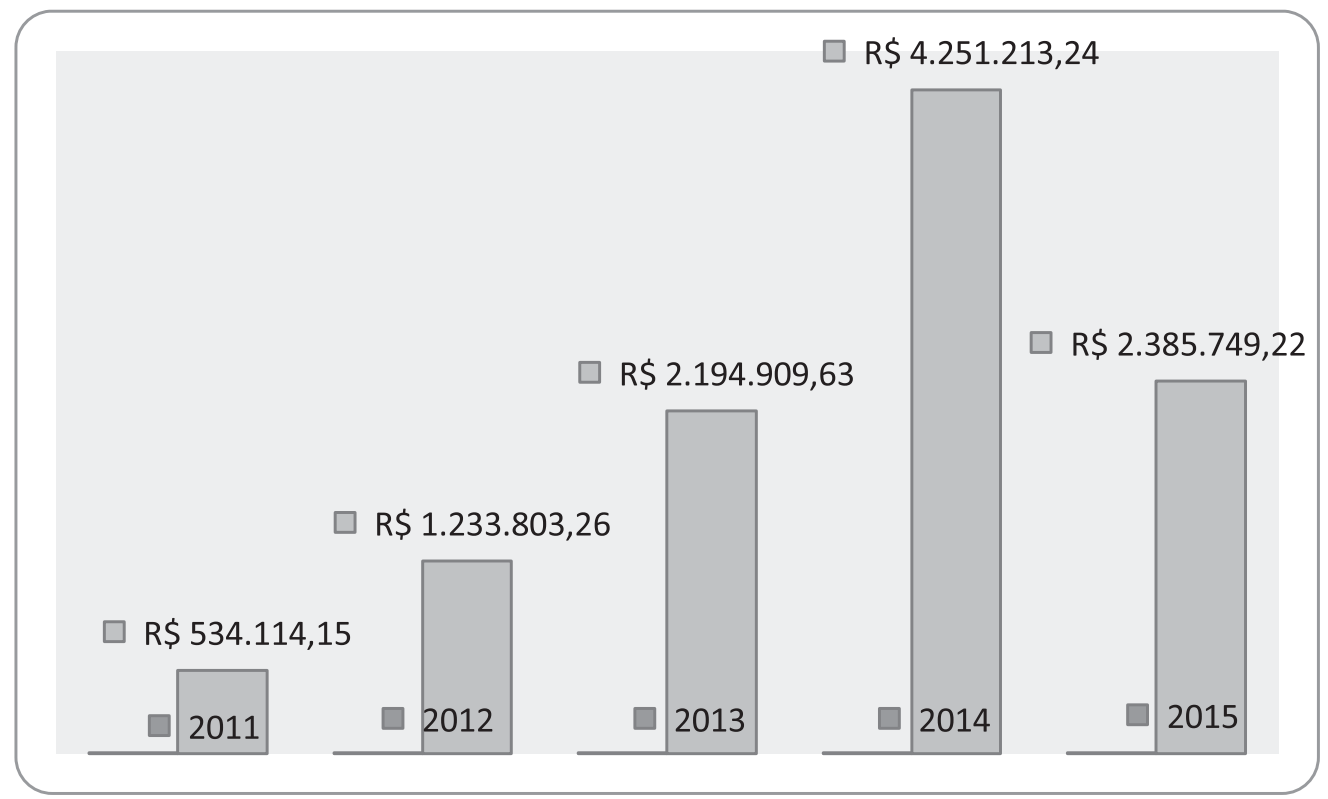

Fonte: Secretaria da Fazenda do Estado do Tocantins - SEFAZ/TO (2017). 
Em 2014, pela primeira vez na história do município, a arrecadação do ICMS Ecológico foi maior que aquela calculada para o ICMS. Segundo índices da Secretaria da Fazenda do Estado do Tocantins, o quesito "terras indígenas" foi o mais relevante na arrecadação do ICMS Ecológico. Verifica-se, também, a contribuição da população indígena Apinajé na arrecadação do ICMS, já que operam grande parte de suas transações financeiras e comerciais nesse município. Neste ponto, pouco se pode avançar sem registrar a importância deste dado para a compreensão da contribuição da população Apinajé para a arrecadação do ICMS, a partir de critérios estritamente econômicos ${ }^{4}$. Por outro lado, os dados relativos ao ICMS Ecológico não deixam dúvidas sobre a importância da terra indígena Apinajé para arrecadação do município de Tocantinópolis, uma vez que entre 2011 e 2015, em média, os repasses do ICMS Ecológico passaram a compor aproximadamente $50 \%$ da arrecadação total do ICMS.

No caso do município de Maurilândia, deparamo-nos com outra situação. Ali o ICMS Ecológico é a parte mais significativa da arrecadação municipal. Excetuando a arrecadação de 2013, bastante inferior a dos anos anteriores. $\mathrm{O}$ gráfico abaixo apresenta o valor proporcional do ICMS e do ICMS Ecológico, demonstrando o grau de dependência da cidade de Maurilândia em relação os repasses do ICMS Ecológico.

\section{Gráfico 3 - Proporção dos repasses do ICMS e ICMS Ecológico no município de Maurilândia}

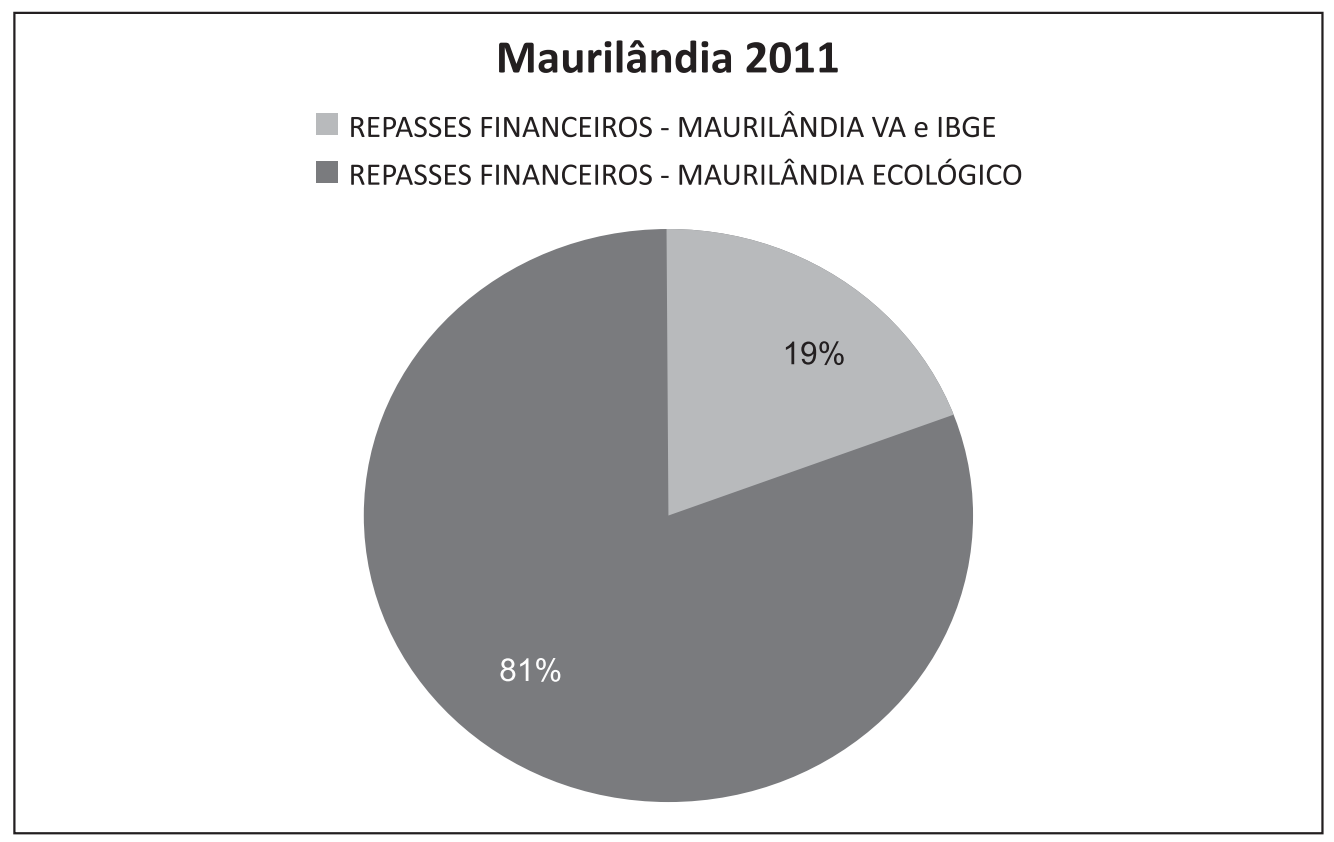

Fonte: Bandeira (2014). 4 Aqui não podemos
avançar muito tendo em
vista que os dados públicos
(e oficiais) sobre a renda
e consumo dos povos
indígenas nos município são
praticamente inexistentes.
Caberia indicá-lo como um
futuro foco de pesquisas
sobre a contribuição dos
indígenas na arrecadação
municipal segundo critérios
estritamente econômicos. 
O gráfico apresentado para o caso de Maurilândia pode perfeitamente ser aplicados para o município de Cachoeirinha, que tem cerca de $41 \%$ de sua área sobreposta ao território Apinajé. Tal como Maurilândia, Cachoeirinha tem no ICMS Ecológico uma importante fonte de recursos advindos deste tributo constitucional. Segundo dados do Naturatins para o ano de 2014, a contribuição do território apinajé para os municípios de Tocantinópolis, Maurilândia e Cachoeirinha foi o seguinte:

Tabela 5 - Repasses do ICMS Ecológico para os municípios de Tocantinópolis, Cachoeirinha e Maurilândia em 2014

\begin{tabular}{l|r}
\hline \multicolumn{2}{c}{ ICMS Ecológico - Terras Indígenas - 2014 } \\
\hline Município & Total arrecadado (R\$) \\
\hline Cachoeirinha & $246.996,47$ \\
\hline Maurilândia do Tocantins & $749.316,15$ \\
\hline Tocantinópolis & $2.007 .437,26$ \\
\hline
\end{tabular}

Fonte. Morais; Demarchi; Bandeira (2015).

Os dados financeiros sistematizados nas tabelas e gráficos apresentados até aqui são persuasivos e evidenciam que as terras indígenas participam do desenvolvimento local, na medida em que fomentam o repasse de recursos para os municípios. Do ponto de vista da arrecadação do ICMS Ecológico, conforme a legislação do estado do Tocantins, as terras indígenas se tornam, assim, a principal fonte de arrecadação de alguns municípios tocantinenses. 0 programa de pesquisa que será apresentado propõe tomar este fato como pressuposto para entender o ICMS Ecológico como uma política pública que deve ser compartilhada com os povos indígenas, tanto no que tange aos recursos financeiros quanto no sentido de ações que minimizem os impactos ambientais produzidos pela política desenvolvimentista e agroindustrial que avança sobre estes territórios, verdadeiras "ilhas de biodiversidade" do bioma Cerrado. 


\section{CONSIDERAÇÕES FINAIS}

Tanto o panorama ambiental e fundiário exposto anteriormente quanto os dados relativos aos repasses do ICMS Ecológico indicam que essa política pública tem o potencial de apresentar soluções concretas para alguns dos problemas ambientais e sociais gerados pelo modelo desenvolvimentista no estado do Tocantins. Todavia, para que isso ocorra, é necessário que os gestores públicos compreendam o ICMS Ecológico como uma política socioambiental, não como uma ação compensatória, logo, restituindo assim sua simetria.

Assim, propõe-se a construção de um programa de pesquisa com objetivo principal de produzir análises etnográficas da gestão pública do ICMS em municípios sobrepostos aos territórios indígenas no Tocantins. Para tal, enfatizam-se duas formas de entender o ICMS Ecológico e o seu uso pelos gestores municipais no sentido de garantir a conservação ambiental e, mais importante, as expressões culturais dos povos indígenas.

Da Matta (1976), a partir de uma análise sistêmica da situação de contato interétnico, argumentou que dois fatores estruturais orientam as relações entre a população não indígena de Tocantinópolis e os Apinajé: a proximidade física e a distância cultural. Se o primeiro componente une as duas sociedades em territórios contíguos, o segundo componente, porém, é frequentemente objeto de litígio. Essa disjunção pode ser solucionada de duas maneiras, argumenta Da Matta: uma postura assimétrica, que assume a proximidade física e nega a diferença cultural, logo criando representações distorcidas e preconceituosas; e uma postura simétrica, assumindo as diferenças culturais e a proximidade física.

Para efeitos deste texto, propõe-se uma atualização da análise de Da Matta para o contexto da relação entre terras indígenas e ICMS Ecológico no Tocantins. Nesse sentido, podem-se configurar duas posturas sobre a aplicação dos recursos arrecadados pelo erário público municipal em decorrência da sobreposição da terra indígena.

A primeira postura, a assimétrica, assume a proximidade física e nega reiteradamente a distância cultural. Aplicado ao ICMS Ecológico, 
essa postura realiza uma leitura estreita de seus princípios legais, entendendo-o como uma compensação financeira aos municípios pelo fato de se considerar as terras indígenas como "latifúndios improdutivos". Essa expressão rebuscada de "economicismo" e de assimetria revela significados profundos, os quais remetem a temas caros ao pensamento evolucionista, altamente retrógado e questionado em todas as suas bases na antropologia e, de forma mais ampla, nas ciências humanas. A "falta de produção indígena" lembra a forma como os pensadores europeus classificavam os povos ditos "primitivos", "sem fé, nem lei, nem rei" e nem economia. Esse pensamento é altamente etnocêntrico, pois julga e classifica assimetricamente outras sociedades e culturas, tomando como pressuposto suas próprias noções de política, religião e economia. Nos termos do ICMS Ecológico, a implicação dessa postura é um baixo retorno para as terras indígenas em termos de investimentos em projetos que atendam suas demandas próprias e que minimamente contemplem os critérios estabelecidos pelo Naturatins. Dessa maneira, os recursos advindos do ICMS Ecológico são utilizados para outros fins.

Essa postura foi detectada por Simioni (2009), quando analisou a relação do município de Turvo (PR) com a terra indígena de Marrecas, no estado do Paraná, quanto à aplicação dos recursos do ICMS Ecológico. A autora observa que:

Em que pese o fato do ICMS Ecológico estar, de um modo geral, gerando efeitos benéficos para o município de Turvo, existem várias dificuldades, tais como: 1. a gestão do recurso por parte dos municípios, posto que o ICMS Ecológico é um tributo não vinculado, ou seja, não se exige contrapartida, o município recebe esse recurso e aplica onde quer e como quer. Como existem áreas emergentes e que demandam maior comoção social, o prefeito desse município tende a aplicar esses valores nas áreas de saúde, educação, entre outros; 2 . a valorização da questão ambiental frente às outras áreas da prefeitura, uma vez que o administrador municipal acredita que outras questões são mais importantes que a preservação ambiental. Atualmente, a única forma de fazer com que o município destine recursos para as terras indígenas é a avaliação feita anualmente pelo IAP [Instituto Ambiental do Paraná]. (SIMIONI, 2009, p. 83). 
Dados preliminares, obtidos por meio de análise empírica em andamento no âmbito do projeto de pesquisa "ICMS Ecológico e Terras Indígenas em Tocantins", permitem afirmar que a situação no estado do Tocantins faz considerar por inteira a passagem acima para os casos estudados aqui. No Tocantins, a situação atual é muito semelhante à apontada por Simioni. As poucas iniciativas de preservação ambiental ainda são tímidas e se contentam em realizar serviços básicos e já obrigatórios da administração municipal, como a coleta de lixo.

Propõe-se outra forma de entender a relação entre ICMS Ecológico e terras indígenas, e logo se volta à segunda postura apontada por Da Matta (1976) para as relações interétnicas. Entende-se que a simetria e a convivência intercultural implicam respeito aos valores culturais específicos dos dois grupos em situação de contato. Essa é, portanto, uma postura que absorve os conhecimentos e valores produzidos, ensinados e compartilhados pela disciplina antropológica ao longo do século XX, tais como relativismo cultural, alteridade, e respeito à diferença. Segundo Da Matta, ao assumir a proximidade física e a distância cultural, "teríamos um conjunto de sociedades diferentes formando uma federação, todas como unidades do mesmo peso dentro de um sistema". (DA MATTA, 1976, p. 51).

Segundo nossa visão, essa rotação de perspectiva, teria três implicações básicas para a forma como o estado e os municípios devem compreender e implementar o ICMS Ecológico. Todas elas são garantidas legalmente pela própria Constituição Federal e pelas tratativas internacionais assinadas pelo Brasil, como a Convenção 169 da Organização Internacional do Trabalho. As implicações seriam: 1) o reconhecimento da terra indígena como um importante critério para arrecadação municipal no que se refere aos repasses do ICMS Ecológico; 2) a garantia da participação indígena nas diferentes etapas de formulação de políticas públicas socioambientais, tal como disposto na lei 1.323/2002 do estado do Tocantins e na resolução da COEMA/TO de 2013, que regulamenta os critérios quantitativos e qualitativos de cálculo do ICMS Ecológico; e, mais importante, 3) a vinculação de uma percentagem do ICMS Ecológico na lei orgânica municipal que garanta aos povos indígenas 
recurso financeiro para a execução de projetos socioambientais como forma de redimir minimamente os avanços inexoráveis do agronegócio sobre suas terras.

Assim, defende-se uma postura simétrica dos municípios em relação às terras indígenas, pois se reconhece que não há obrigação constitucional em relação a elas no que tange aos repasses do ICMS Ecológico. Teriam, sim, uma obrigação, no mínimo, moral, de retribuir aos povos indígenas uma parte significativa dos repasses advindos do ICMS Ecológico. Essa obrigação deveria se tornar uma questão legal, uma vez que os municípios têm plena autonomia em vincular um tributo fiscal, como é o caso do ICMS Ecológico, em sua lei orgânica municipal, tornando-a uma política pública voltada diretamente aos povos indígenas do estado do Tocantins.

\section{Referências}

BANDEIRA, M. do S. G. ICMS Ecológico e Terras Indígenas na região do bico do papagaio. 2014. Trabalho de Conclusão de Curso (Graduação em Ciências Sociais) - Universidade Federal do Tocantins, Tocantinópolis, 2014.

BARBOSA FILHO, J. O. F. Os Apinajé em Tocantinópolis: ICMS Ecológico e relações interétnicas no bico do papagaio. 2014. Trabalho de Conclusão de Curso (Graduação em Ciências Sociais) - Universidade Federal do Tocantins, Tocantinópolis, 2014.

BRASIL. Constituição (1988). Constituição da República Federativa do Brasil: texto constitucional promulgado em 5 de outubro de 1988, com as alterações adotadas pelas Emendas Constitucionais nos 1/1992 a 68/2011, pelo Decreto Legislativo n 186/2008 e pelas Emendas Constitucionais de Revisão nos 1 a 6/1994. - 35. ed. - Brasília: Câmara dos Deputados, Edições Câmara, 2012.

Ministério do Meio Ambiente. Instituto Chico Mendes. A cada segundo 15 animais silvestres morrem atropelados. 2014. Disponível 
em: <http://www.icmbio.gov.br/portal/comunicacao/noticias/4destaques/4944-a-cadasegundo-15-animais-silvestres-morrematropelados-no-brasil.html>. Acesso em: 8 jun. 2015a.

Ministério do Meio Ambiente. Monitoramento do desmatamento nos biomas brasileiros por satélite: acordo de cooperação técnica MMA/ IBAMA - Monitoramento do Bioma Cerrado 2009-2010. Brasília, DF, 2011.

. Ministério do Meio Ambiente. Plano de Ação para Prevenção e Controle do Desmatamento e das Queimadas no Cerrado - PPCerrado. Brasilia, DF, 2009.

. Ministério do Meio Ambiente. Plano de Ação para prevenção e controle do desmatamento na Amazônia Legal (PPCDAm): $3^{\text {a }}$ fase (20122015) pelo uso sustentável e conservação da Floresta / Ministério do Meio Ambiente e Grupo Permanente de Trabalho Interministerial. Brasília, DF, 2013.

. Decreto $\mathrm{n}^{\circ} \mathbf{2 . 6 5 2}$, de $\mathbf{1}^{\circ} \mathrm{de}$ julho de 1998 . Promulga a Convenção das Nações Unidas sobre Mudança do Clima, assinada em Nova York, em 9 de maio de 1992. Disponivel em: <http://http://www.planalto. gov.br/ccivil_03/decreto/D2652.htm>. Acesso em: 8 jun. 2015.

Decreto $\mathbf{n}^{\circ} \mathbf{8 . 4 4 7}$, de 6 de maio de 2015. Dispõe sobre o Plano de Desenvolvimento Agropecuário do Matopiba e a criação de seu Comitê Gestor. Brasilia, DF, 2015b. Disponível em: <http://www.planalto.gov.br/ ccivil_03/_Ato2015-2018/2015/Decreto/D8447.htm>. Acesso em: 8 jun. 2015.

. Decreto n 5.051, de 19 de abril de 2004. Promulga a Convenção no 169 da Organização Internacional do Trabalho - OIT sobre Povos Indígenas e Tribais. Disponivel em: http://www.planalto.gov.br/ccivil_03/_ ato2004-2006/2004/decreto/d5051.htm. Acesso em: 10 de março de 2017.

. Câmara dos Deputados. Proposta de Emenda à Constituição 215 - PEC-215. Inclui dentre as competências exclusivas do Congresso 
Nacional a aprovação de demarcação das terras tradicionalmente ocupadas pelos índios e a ratificação das demarcações já homologadas; estabelecendo que os critérios e procedimentos de demarcação serão regulamentados por lei. Disponivel em: <http://www.camara.gov.br/ proposicoesWeb/fichadetramitacao?idProposicao=14562>. Acesso em: 10 de março de 2017.

DA MATTA, R. ;A. Um mundo dividido: a estrutura social dos índios Apinayé. Petrópolis: Vozes, 1976.

EMPRESA BRASILEIRA DE PESQUISA AGROPECUÁRIA. Matopiba: delimitação, caracterização, desafios e oportunidades para o desenvolvimento. Campinas: EMBRAPA, 2014a. Disponivel em: <https:// www.embrapa.br/gite/projetos/matopiba/150514_MATOPIBA_MA.pdf>. Acesso em: 19 dez. 2016.

EMPRESA BRASILEIRA DE PESQUISA AGROPECUÁRIA. Matopiba: quadro natural. Campinas: EMBRAPA, 2014b. Disponivel em: <https://www. embrapa.br/gite/publicacoes/NT5_Matopiba_Quadro_Natural.pdf>. Acesso em: 19 dez. 2016.

INSTITUTO NACIONAL DE PESQUISAS ESPACIAIS. Metodologia para o Cálculo da Taxa Anual de Desmatamento na Amazônia Legal. São José dos Campos: INPE, 2013.

INSTITUTO SOCIOAMBIENTAL. Povos Indígenas no Brasil. 2015. Disponível em: < https://povosindigenas.org.br/pt>. Acesso em: 08 de jan. 2017.

LAKATOS, E. M.; MARCONI, M. A. Fundamentos de metodologia científica. 5. ed. São Paulo: Atlas, 2003.

LOUREIRO, W. Contribuição do ICMS Ecológico à conservação da biodiversidade no Estado do Paraná. 2002. Tese (Doutorado em Engenharia Florestal) - Universidade Federal do Paraná, Curitiba, 2002.

LOUREIRO, W. O ICMS Ecológico, um instrumento econômico de gestão ambiental aplicado aos municípios. 2006. Disponível em: http://www. 
icmsecologico.org.br/site/images/artigos/a020.pdf. Acesso em: 02 abril 2014.

MORAIS, O.; DEMARCHI, A.; BANDEIRA, M. do S. G. ICMS Ecológico e Terras Indígenas em Tocantins: o caso Apinajé. In: SILVA, R. P. (Org.). Povos indígenas do Tocantins: desafios contemporâneos. Palmas: Nagô, 2015. p. 157-178.

MORAIS, O. ICMS Ecológico e Terras Indígenas em Tocantins: o caso Xerente. In: MACHADO, M. Culturas e história dos povos indígenas, vol. 1. Fortaleza: Expressão; Universidade Federal do Ceará, 2016. p. 111-130.

SECRETARIA DA FAZENDA DO ESTADO DO TOCANTINS. Repasses do ICMS. 2017. Disponivel em: http://www.sefaz.to.gov.br/repasses/icms. php. Acesso em: 08 de jan. 2017

SILVA, L. A. G. C. Biomas presentes no estado do Tocantins. Brasilia, DF: Câmara dos Deputados, 2007.

SIMIONI, M. de P. ICMS Ecológico e terras indígenas: um estudo de caso da Reserva Indígena de Marrecas-PR. 2009. Dissertação (Mestrado em Desenvolvimento Econômico) - Departamento de Economia, Setor de Ciências Sociais Aplicadas, Universidade Federal do Paraná, Curitiba, 2009.

TOCANTINS. ICMS Ecológico: manual de orientações técnica. Governo do estado do Tocantins, Instituto de Natureza do Tocantins, 2008.

Decreto $\mathbf{n}^{\mathbf{1}} \mathbf{1 . 6 6 6}$, de 26 de dezembro de 2002. Regulamenta a Lei 1.323 , de 4 de abril de 2002, que dispõe sobre os índices que compõem o cálculo da parcela do produto da arrecadação do ICMS pertencente aos Municípios. Disponivel em: http://dtri.sefaz.to.gov.br/legislacao/ ntributaria/decretos/Decreto1.666.02.htm. Acesso em: 10 de março de 2017.

Decreto $\mathbf{n}^{\circ} \mathbf{7 1 . 1 0 7}$, de 14 de setembro de 1972. Declara reserva indígena área situada no município de Tocantínia, Estado de Goiá. Disponivel em: http://www2.camara.leg.br/legin/fed/decret/1970-1979/ 
decreto-71107-14-setembro-1972-419942-publicacaooriginal-1-pe. html>. Acesso em: 10 de março de 2017.

Decreto n 76.999, de 08 de janeiro de 1976. Dispõe sobre o processo administrativo de demarcação das terras indígenas. Disponível em: <http://www2.camara.leg.br/legin/fed/decret/1970-1979/decreto76999-8-janeiro-1976-425608-publicacaooriginal-1-pe.html>. Acesso em: 08 de março de 2017.

Decreto n 97.838, de 16 de junho de 1989. Homologa a demarcação administrativa da Área Indígena Xerente que menciona, no Estado do Tocantins. Disponível em: http://www2.camara.leg.br/legin/ fed/decret/1989/decreto-97838-16-junho-1989-439417-norma-pe. html. Acesso em: 10 de março de 2017.

Decreto n² 269, de outubro de 1991. Homologa a demarcação administrativa da Área Indígena Funil, no Estado do Tocantins. Disponível em: <http://www.planalto.gov.br/ccivil_03/decreto/1990-1994/D269. htm>. Acesso em: 10 de março de 2017.

Resolução N. 40 de 27 de agosto de 2013. Dispõe sobre o questionário de avaliação qualitativa do ICMS. Tocantins, TO, 2017. Disponivel em: <https://central3.to.gov.br/arquivo/278585/> Acesso em: 08 abril, 2017.

Recebido em 30/04/2016 Aprovado em 03/10/2016 